\title{
The characteristics of the Greek athletes of race walking in relation to the frequency of injuries
}

\author{
Fitili P.I. ${ }^{A B C D E}$, Giovanis V.F. ${ }^{A B C D E}$, Sanidopoulos G.N. ${ }^{A B C D E}$ \\ School of Physical Education and Sports Science, National and Kapodistrian University of Athens, Greece
}

Authors' Contribution: A - Study design; B - Data collection; C - Statistical analysis; D - Manuscript Preparation; E - Funds Collection.

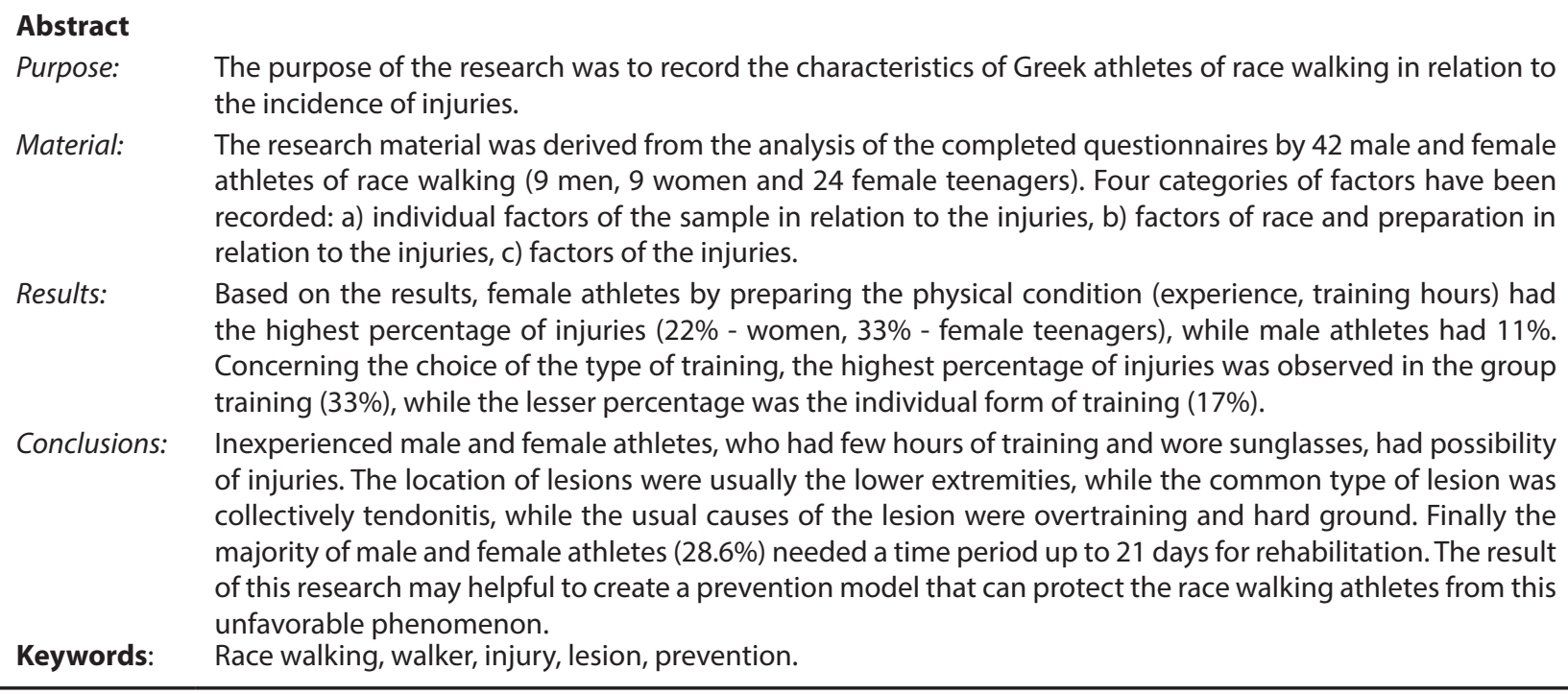

\section{Introduction}

Race walking is one of the Olympic sport events of classic sports. The athletes move as fast as possible without running at distances up to $50 \mathrm{~km}$ and $20 \mathrm{~km}$ while female athletes participate in a race up to $20 \mathrm{~km}$.

Race walking takes place on public roads with flat soil morphology [1]. The athletes cover a distance, e.g. $20 \mathrm{~km}$, repeating 10 times $2 \mathrm{~km}$ or 4 times $5 \mathrm{~km}$. The essential difference between race walking and running is that for the first one, special rules have been followed that have been enacted. Also not only for the correct technique that will allow athletes to perform well, but to comply with the provisions of specific guidelines for the event. There are, therefore, some rules that differentiate race walking from running and race walkers must know and follow them faithfully. The forward foot should be stretched (ie not bending the knee) from the moment of first contact with the ground until it reaches a vertical upright position [2]. The judges watch the athletes and exclude them if their feet are not completely straight when they hit the ground or if both legs lose contact with it. When the judge finds an offense, he makes his first remark. If the offense is repeated, then the warning to block the athlete is placed on a sign visible to all participants in the race. If three judges charge the particular athlete with an offense, then he is excluded [1].

The following scientists have dealt with the race walking technique: Ruchlewicz et al. [3] have dealt with the parameters of biomechanics of racing walking based on research at an international level athlete. Chwala et

(c) Fitili P.I., Giovanis V.F., Sanidopoulos G.N., 2018

doi:10.15561/18189172.2018.0303 al. [4] have dealt with the effect of space-time values on the determination of the general body mass center in the increased speed of racing walking in the group of championship walkers. Hanley et al. [5, 6] have dealt with biomechanical analysis of elite race walkers, technique analysis and the effects of fatigue. Staszkiewicz et al. [7] have dealt with have dealt with the vertical and lateral displacement of the center of gravity while walking with natural frequency of the steps. While Aschenbrenner et al. [8] have dealt with the tactics of race walking. Yioshida et al. [9] \& Cottin et al. [10] have dealt with the specificities of physiological adaptations to resistant training in athletes of race walking. The literature on the study of the epidemiology of injuries-lesions in race walking is limited and has been approached by the following scientists: [10, 11]. Chojnacki [12-14] have dealt with the prevention and risk of injuries and accidents in alpine skiing.

The purpose of the research was to record the characteristics of Greek athletes of race walking in relation to the incidence of injuries.

The wording of the assumptions was based on the following questions: are there any possibilities of injuries in athletes of race walking who prepare their physical condition before racing season and before the race? Could results of the research be helpful to create a prevention model that can protect the athletes from this unfavorable phenomenon?

\section{Material and methods}

Sample. 42 Greek athletes (9 men, 9 women and 24 female teenagers) participated in the research and were 
selected by random sampling.

Means of data collection. The research material resulted from the analysis of completed questionnaires out of 42 Greek male and female athletes of the race walking. Questionnaires of diachronic studies were used for skiers of the following researchers: Horczynski [15], Chojnacki $\&$ Giovanis [16], Giovanis [17, 18], and Giovanis et al. [19]. Four categories of factors have been recorded:

(a) individual factors of the sample in relation to the injuries [age, sex, stature, body mass and body mass index (BMI)];

(b) physical and race preparation factors in relation to injuries (time of training in years and hours);

(c) factors of the injuries (injury existence, type of injury, location of injury, cause of injury and time of rehabilitation in days).

Data collection process. The data collection took place during the summer season 2015, July and August, during a planned summer training at a seaside camp. The questionnaires were given to each athlete separately, after having been informed about the purpose of the survey and how the questionnaires should be completed. 50 questionnaires were given and 42 were returned (return rate $84 \%)$.

Descriptive statistical analysis. Each specific group of athletes corresponds to three categories of statistics: number of participants, number of injured athletes and the percentage of injuries (Excel 2007 program). Descriptive statistical analysis of the results of epidemiological research has helped to illustrate the causes and factors of injuries in race walking.

\section{Results}

\section{A) Individual factors of the sample in relation to the} injuries

The 42 respondents were aged 11 to $44(18 \pm 6.77)$. The mean height rate of male was $1.78 \pm 0.07$, for female $1.68 \pm 0.06$, and for female teenagers $1.61 \pm 0.05$. Also, the body weight of male was $61.06 \pm 7.88$, of female $57.11 \pm 4.51$, while of female teenagers was $48.75 \pm 6.52$. Finally, male Body Mass Index (BMI) values were 19.30 \pm 1.86 , female $20.38 \pm 1.79$, and $18.72 \pm 2.41$ for female teenagers, where the B.M.I was normal for both genders (Table 1).

Figure 1 concludes that female teenagers had the highest rate of injuries (33\%) than men (11\%) and women

Table 1. The anthropometric characteristics of the Greek race walkers

\begin{tabular}{|c|c|c|c|c|c|c|c|c|c|c|}
\hline \multirow[t]{2}{*}{$\begin{array}{l}\text { ATHLETES } \\
\text { (n) }\end{array}$} & \multicolumn{2}{|l|}{$\begin{array}{l}\text { MALE } \\
(n=9)\end{array}$} & \multicolumn{2}{|c|}{ FEMALE (n=9) } & \multicolumn{2}{|c|}{$\begin{array}{l}\text { FEMALE } \\
\text { TEENAGERS } \\
(\mathrm{n}=\mathbf{2 4})\end{array}$} & \multicolumn{2}{|c|}{$\begin{array}{l}\text { TOTAL } \\
(n=42)\end{array}$} & \multirow[b]{2}{*}{ MIN } & \multirow[b]{2}{*}{ MAX } \\
\hline & $M$ & SD & $M$ & SD & $M$ & SD & $\mathrm{M}$ & SD & & \\
\hline AGE (years) & 18 & 2.23 & 27 & 8.88 & 14 & 1.57 & 18 & 6.77 & 11 & 42 \\
\hline HEIGHT (m) & 1.78 & 0.07 & 1.68 & 0.06 & 1.61 & 0.05 & 1.66 & 0.09 & 1.50 & 1.92 \\
\hline WEIGHT (kg) & 61.06 & 7.88 & 57.11 & 4.51 & 48.75 & 6.52 & 53.18 & 8.27 & 36 & 70 \\
\hline $\mathrm{BMI}\left(\mathrm{kg} / \mathrm{cm}^{2}\right)$ & 19.30 & 1.86 & 20.38 & 1.79 & 18.72 & 2.41 & 19.20 & 2.24 & 15.06 & 26.91 \\
\hline
\end{tabular}

$\mathrm{n}$ - number of athletes $\mathrm{M}$ - mean SD - standard deviation

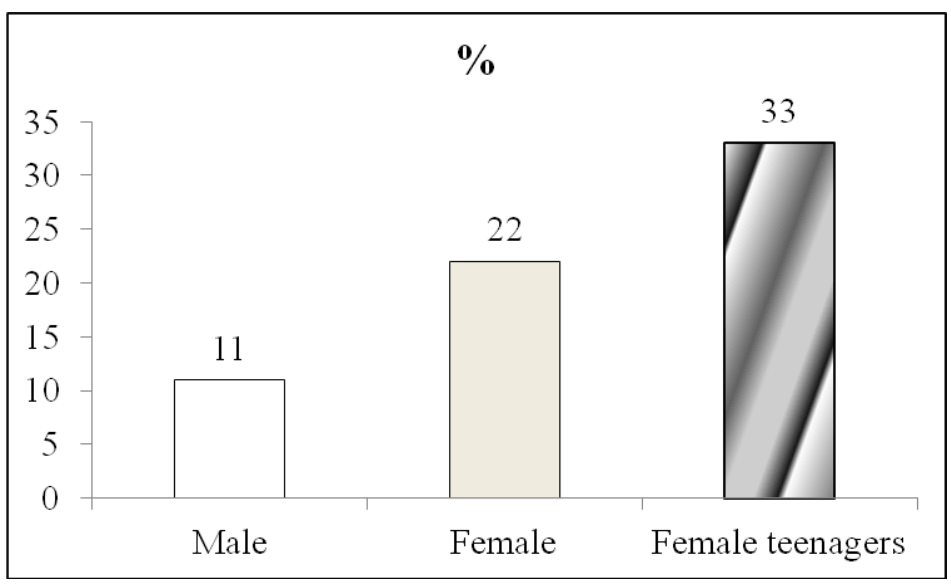

Figure 1. The percentage of injuries related to sex and category of athletes 
(22\%).

B) Preparation and race factors in relation to injuries

The highest rate of injury in relation to years of experience concerned athletes with $3<5$ years (41\%), while the lowest percentage concerned athletes with $11 \leq$ years $(5 \%$ - Figure 2$)$. The highest rate of injuries in relation to the hours of training concerned athletes with $1.5<2$ hours of training $(77 \%)$. The lowest percentage were those with $0.5<1$ hour (5\%) and over 3.5 hours (Figure 3).
Figure 4 shows the injury rates in relation to training choices, with the largest share was that of the group training (33\%), while the lesser was the individual training $(17 \%)$.

The highest percentage of injuries, depending on the type of effort and the distance, were male and female athletes during the training. While the lowest percentage of injuries were athletes in the $50 \mathrm{~km}$ race (Figure 5).

A notable phenomenon is that people who participated in the race or training with sunglasses are the same people

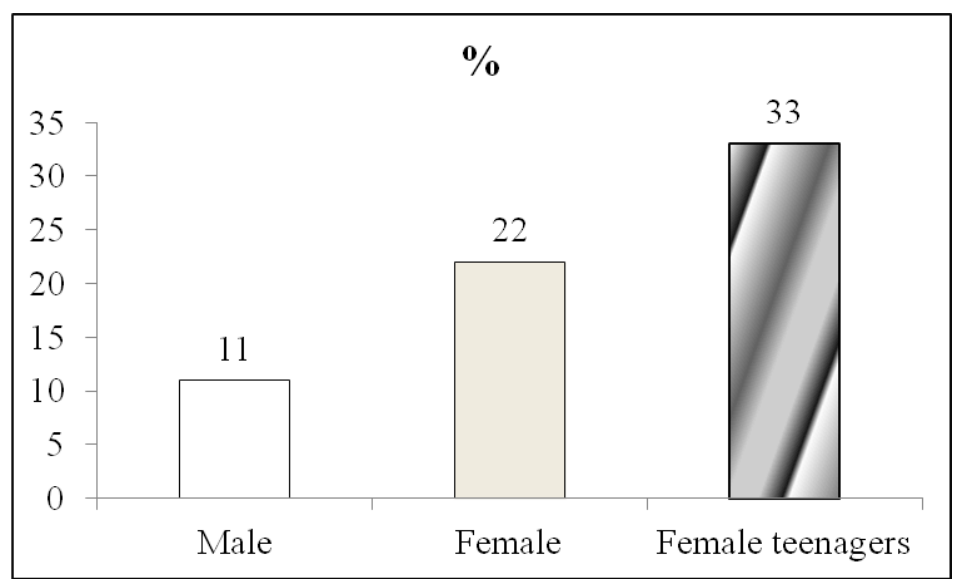

Figure 2. The percentage of injuries related to years of experience

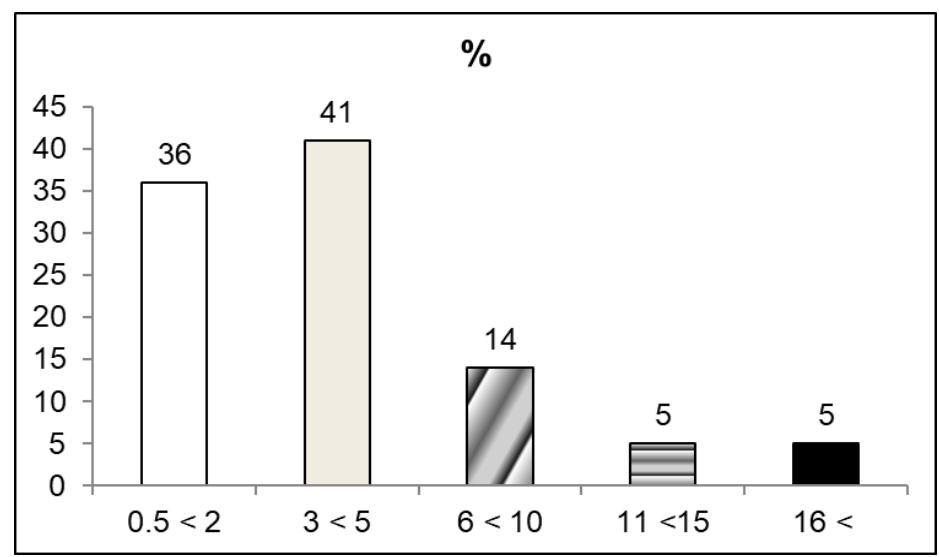

Figure 3. The percentage of injuries related to training hours

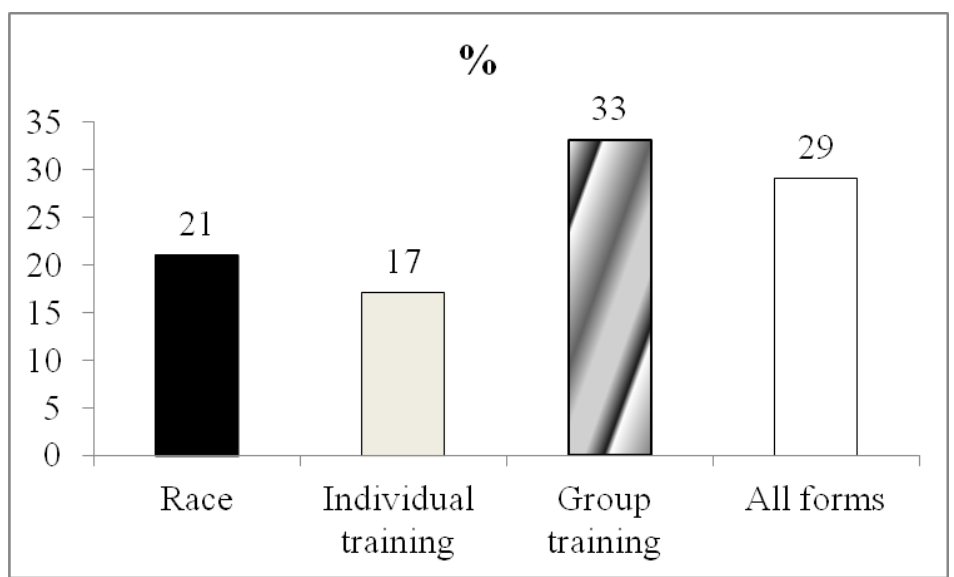

Figure 4. The percentage of injuries in relation to training form 
who have been canceled in the match and had the most injuries (100\% - Table 2).

\section{C) Factors of injuries}

The location of injury was usually the lower extremities, while the common type of injury was tendonitis (38\% figure 6). The usual causes of the injury were overtraining (48\%) and hard ground (14\% - Figure 7).

Most male and female athletes (28.6\%) wanted a rehabilitation time up to 21 days (Figure 8).

\section{Discussion}

In a study composed by Hanley [5, 6] on the kinematics variables of competitive athletes in race walking, 40 highlevel athletes took place. From these athletes, 15 were men competing in the $20 \mathrm{~km}$ and $50 \mathrm{~km}$ races, while 7 were women competing in $20 \mathrm{~km}$ race. The 10 were male teenagers at $10 \mathrm{~km}$ and 8 were female teenagers at 5 $\mathrm{km}$. Kinetic data were collected at $2.5 \mathrm{~km}$ of the course. The study found that men had a longer stride length than women and therefore marched faster. On average, the flight time in both groups was about $0.04 \mathrm{sec}$. Vertical forces were observed characteristic of race walking in the group of adult athletes, relative with the group of young athletes, which reveals the training experience of the adult team in the technique of the competition. In males and

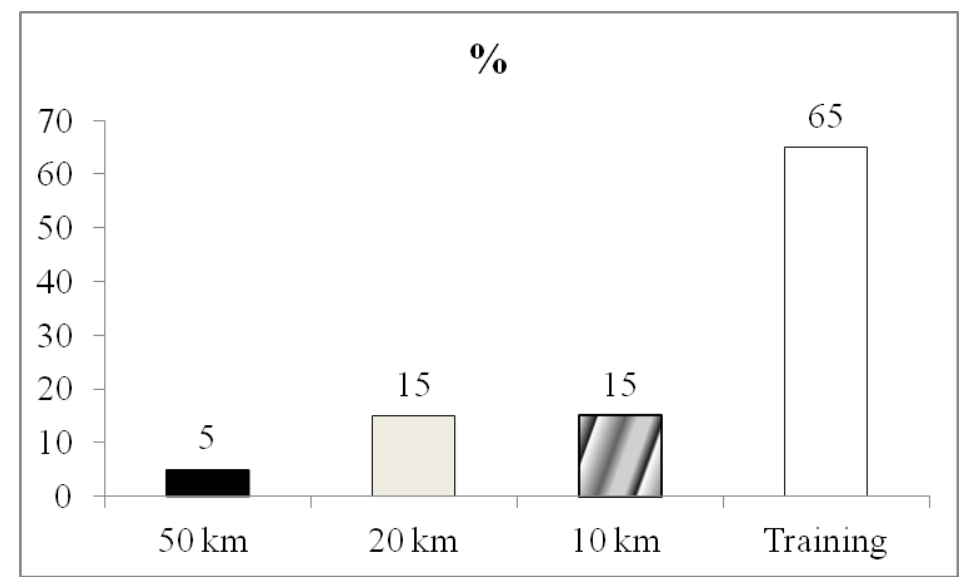

Figure 5. The percentage of injuries in races and training

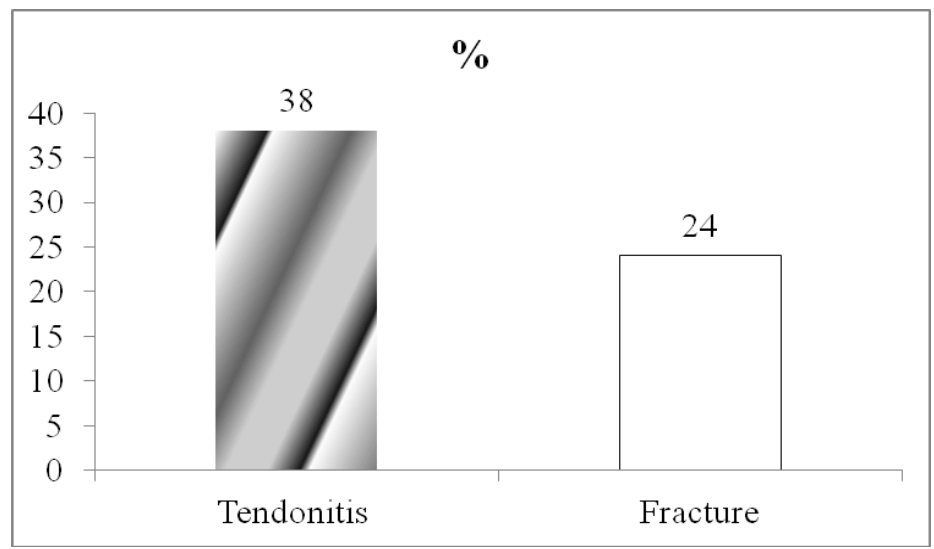

Figure 6. The usual type of injury in race walking

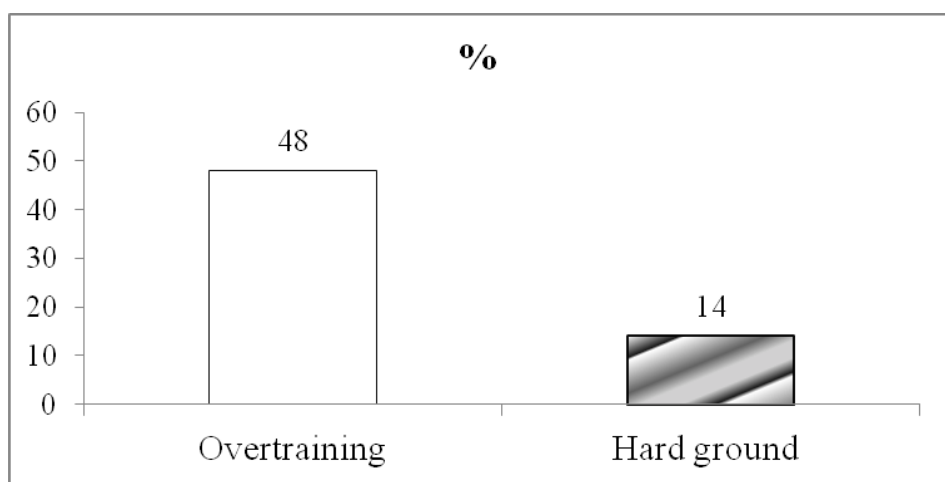

Figure 7. The common causes of the injury 


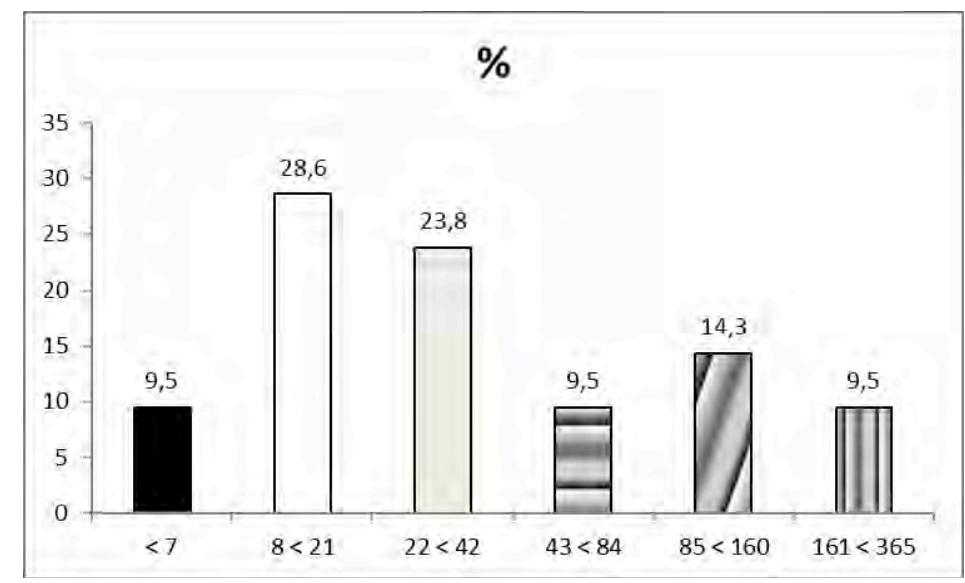

Figure 8. Time (in days) of rehabilitation of injuries

females, there was a significant correlation of speed with the length of the stride. Finally, there was a significant correlation between the height of the athletes and their length of stride, and no corresponding correlation was found among females. The literature on the study of the epidemiology of injuries-lesions in competitive race walking is limited. Comparing the Hanley study $[14,16]$ with this study justifies the highest incidence of injuries in female athletes (22\%) and female teenagers (33\%) in relative to the injury rate of male athletes (11\% - figure 1$)$. The phenomenon that the people who participated in the race or training with sunglasses are the same people who have been canceled in the race and suffered most injuries. The above phenomenon is justified by inexperience, the few hours of training with inadequate concentration and misallocation of forces during the conduct of the course race.

\section{Conclusions - Proposals}

Based on the results, female athletes by preparing the physical condition (experience, training hours) had the highest percentage of injuries (22\% - women, 33\% - female teenagers), while male athletes had $11 \%$. Concerning the choice of training form, the highest percentage of injuries was observe in the group training (33\%), while the lesser percentage was the individual form of training (17\%). Male and female athletes with inexperience, few hours of training and wearing sunglasses have a chance of injuries. The location of lesion were usually the lower extremities, while the common type of lesion was tendonitis, and the usual causes of the lesion were overtraining and hard ground. Finally, the majority of the athletes (28.6\%) wanted a rehabilitation time from injuries up to 21 days. The result of this research may help full to create a prevention model that can protect the athletes of race walking from this unfavorable phenomenon.

\section{Conflict of interest.}

The authors state that there is no conflict of interest.

determination of the general body mass center in the increased speed of racing walking in the group of championship walkers]. In: Urbanik Cz. (ed.) Biomechanika sportu $i$ rechabilitacji [Biomechanics of sport and rehabilitation]. Warsaw: AWF; 2007. P.29-43 (in Polish)

5. Hanley B, Bissas A, Drake A. Biomechanical analysis of elite race walkers. Technique analysis and the effects of fatigue. New Studies in Athletics, 2008;4(23):17-25.

6. Hanley B, Bissas A, Drake A. The biomechanics of elite junior race walkers. New Studies in Athletics, 2008;4(25):3947.

7. Staszkiewicz R, Ruchlewicz T, Laska J, Nosiadek L. Pionowe i boczne przemieszczenia srodka ciezkosci podczas chodu z naturalna czestotliwoscia krokow [The vertical and lateral displacement of the center of gravity while walking with natural frequency of the steps]. In:. Urbanik C. (ed.). Wybrane zagadnienia biomechaniki ruchu czlowieka [Selected issues of biomechanics of human movement]. Warsaw: AWF; 2007. P. 29-38. (in Polish)

8. Aschenbrenner P, Erdmann WS, Giovanis V, Lipinska P. Investigations on technique and tactics of race walking during Olympic Games Athens 2004 - first announcement. Proceedings of the XXIV International Symposium on Biomechanics in Sports. University of Salzburg, July, 14-18. 
2006;1:517-520.

9. Yoshida T, Udo M, Iwai K, Muraoka I, Tamaki K, Yamaguchi T, Chida M. Physiological determinants of race walking performance in female race walkers. Br. J. Sport Medicine. 1989;23(4):250 - 254.

10.Cottin F, Slowinski J, Lopes Ph, Van de Louw A, Billat V. Effect of a 24-h continuous walking race on cardiac autonomic control. Eur J Appl Physiol. 2007;99:245-250.

11.Cappozzo A. Analysis of the linear displacement of the head and trunk during walking at different speeds. Journal of Biomechanics, 1981;14(4):411 - 425.

12.Chojnacki K. Praktyczne sposoby, metody i systemy zapobiegania urazowości $w$ narciarstwie zjazdowym. [Practical methods, methods and systems for preventing injuries in alpine skiing]. Kraków: AWF; 1988 (in Polish)

13.Chojnacki K. Najlepsi ryzykuja najwięcej [The best risk the most]. In: Ulatowski (ed.): „Training “, Methodical and training quarterly, 1991;1(9):20-25. (in Polish)

14.Chojnacki K. Studium epidemiologiczne urazowości a zagrożenie wypadkowe $w$ narciarstwie zjazdowym. [Epidemiological study of injuries and accident risk in Alpine skiing]. Kraków: AWF; 1994. (in Polish)
15.Horczyński K. Wypadki narciarskie w rejonie Beskidów w świetle wieloczynnikowej analizy epidemiologicznej. [Skiing accidents in the region of Beskydy in the light of multivariate analysis of epidemiological]. Doctoral dissertation. Katowice; 1978. (in Polish)

16.Chojnacki K, Giovanis V. Porownanie analizy urazowosci w narciarstwie alpejskim w Polsce, Holandii i w Grecji. [The comparative analysis of injuries in downhill skiing of Poland, Holland and Greece]. Medycyna Sportiva, 1996;60/61:45-50 (in Polish)

17.Giovanis V. Kinematyka przejazdow torow slalomowych $w$ narciarstwie alpejskim, a problem urazowosci [Kinematics of slalom courses' runs in alpine skiing and problems of injuries]. Doctoral dissertation. Cracow; 1998. (in Polish)

18.Giovanis V. Ta charaktiristika ton Ellinon chionodromon se schiesi me ti sichnotita tvn atichimaton [The characteristics of Greek skiers related to the frequency of accidents]. Medical Annals, 2009;32:178-184. (in Greek)

19.Giovanis V, Belesiotis K, Bonovolia M. Oi travmatismi ton chionodromon sto Val D' Isere (Galia). [Injuries to skiers in Val D Isere (France)]. Physical Education \& Sports, 2014;34(1):120-126. (in Greek)

\section{Information about the authors:}

Fitili P.I.; http://orcid.org/0000-0001-5682-3047; School of Physical Education and Sport Science, National and Kapodistrian University of Athens; 41 Ethnikis Antistassis Str.; Daphne 17237, Athens, Greece.

Giovanis V.F. (Corresponding author); PhD; http://orcid.org/0000-0003-2511-8286; vgiovan@phed.uoa.gr; School of Physical Education and Sport Science, National and Kapodistrian University of Athens; 41 Ethnikis Antistassis Str.; Daphne 17237, Athens, Greece.

Sanidopoulos G.N.; http://orcid.org/0000-0002-3868-348X; School of Physical Education and Sport Science, National and Kapodistrian University of Athens; 41 Ethnikis Antistassis Str.; Daphne 17237, Athens, Greece.

Cite this article as: Fitili PI, Giovanis VF, Sanidopoulos GN. The characteristics of the Greek athletes of race walking in relation to the frequency of injuries. Pedagogics, psychology, medical-biological problems of physical training and sports, 2018;22(3):130135. doi:10.15561/18189172.2018.0303

The electronic version of this article is the complete one and can be found online at: http://www.sportpedagogy.org.ua/index.php/PPS/issue/archive

This is an Open Access article distributed under the terms of the Creative Commons Attribution License, which permits unrestricted use, distribution, and reproduction in any medium, provided the original work is properly cited (http://creativecommons.org/licenses/by/4.0/deed.en).

Received: 12.12 .2017

Accepted: 20.01.2018; Published: 30.06.2018 